\title{
Trends in MOOCs Research: Analysis of Educational Technology Journals
}

\author{
https://doi.org/10.3991/ijet.v15i17.14637 \\ Abdelghani Babori \\ Hassan First University, Settat, Morocco \\ University of Lille, Lille, France \\ abdelghani.babori@gmail.com
}

\begin{abstract}
Massive open online courses (MOOCs) have received a great deal of interest from educational institutions and private enterprises. Hence, several empirical studies and reviews have been produced. They will be at the heart of the synthesis presented in this article, which reviews the research objects, the analytical frameworks mobilized and the methodologies adopted in the research produced specifically between January 2012 and January 2018. The trends were identified by a review of 36 selected peer reviewed journals. 100 studies were retained after quality assessment. The results show that research questions focused primarily on learning processes followed by design of MOOCs, learning experience and predictors of retention. A variety of frameworks have been adopted in empirical studies. Questionnaires were used as primary collection method and descriptive statistics were the preferred treatment processes.
\end{abstract}

Keywords-MOOC, literature review, research trends, research in MOOCs.

\section{Introduction}

The acronym MOOC stands for massive open online course which is growing in number in recent years. MOOCs are open to any interested person and offer education products for a scalable number of learners who have access to the internet [1], there are hundreds of courses around the world provided to millions of registered users of MOOCS [2]. These courses have prompted major universities and institutions to take a pedagogical view toward developing new design MOOCs and make them available to a global audience in order to promote teaching and learning, and research on MOOCs has extended significantly. Specifically, in the past six years there has been an increasing amount of literature on MOOCs research.

These literature reviews have concentrated on several vast areas such as categorizing academic research relating to MOOCs $[3,4,5,6,7,8]$, exploring research trends in terms of data collection and analysis methods $[9,10]$ or examining a specific theme or a particular issue $[11,12,13,14,15,16,17,18,19,20,21]$. We believe these literature reviews provide a valuable synthesis of MOOCs, but further examination is needed to examine the literature. Indeed, the past reviews failed to examine completely or cate- 
gorize research trends from the point of view of research questions and the mobilized frameworks. This study differs from the past literature reviews by its focus on research questions, frameworks mobilized and methodologies adopted. It expands the previous review of MOOC research by adding more updated papers published between January 2012 and January 2018 in selected high-quality journals.

This paper is organized as follows: Section 2 presents some previous reviews analyzing the research trends on MOOCs. Section 3 describes the methodology adopted to select journals and articles. Section 4 answers the research questions by presenting and analyzing the main obtained results. Section 5 discusses the results by comparing them with previous ones. Conclusions and implication for future work are described in section 6 .

\subsection{Literature review}

Over the past six years, researchers have begun to give careful consideration to trends in research on MOOCs. Some of these studies sought to undertake a comprehensive analysis in order to take stock of the studies at a specific moment, including Bozkurt, Keskin and de Waard [22], Ebben et Murphy [3], Gašević et al. [4], Liyanagunawardena et al., 2013 [5], Veletsianos and Shepherdson [6], Yousef, Chatti, Schroeder, Wosnitza et Jakobs [7] and Zawacki-Richter et al. [8]. The research methods used in these examined literature reviews differ. The majority of selected studies come from databases and journals. The journals were generally selected on the basis of their specialisation in the field of educational technology, their presence in recognised databases such as Scopus and Thomson Reuters or their citation in the bibliographies of identified articles. The selection criteria for the articles included the type of article (research, report of the approach, theoretical analysis, etc.), whether or not it was published within the period covered by the literature review, and the presence of the keywords considered. The review undertaken by Gasaevic et al. [4] is somewhat unusual insofar as these authors analysed research projects submitted to the MOOC Research Initiative (MRI) and no journal or database was thus explored. The review undertaken by Israel [20] was 'narrative reviews' without any systematic methodological process, which explains the absence of the journals or databases examined, or even the number of articles found.

This identified literature which reviewed previous MOOC studies published between 2008 and 2017 have different objectives. The first study on MOOC research trends by Liyanagunawardena et al. [5] reviewed 45 published MOOC studies (published between 2008 and 2012). The Liyanagunawardena et al [5] study identified eight themes in the literature: introductory, concept, case studies, educational theory, technology, participant focused, provider focused, and other. It indicated a significant minor focus on the institutional threats and opportunities. The lack of published research on MOOC facilitators' experience and ethical aspects of using data generated by MOOC participants were identified as a gap in the literature and still to be explored. Similarly, Yousef et al. [7] reviewed 84 MOOC studies to gain a deep understanding of key concepts in this emerging field. The authors used a template analysis to map the conducted research on MOOCs into 7 dimensions: concept, design, learn- 
ing theories, case studies, business model, targets groups, and assessment. That same year, Ebben and Murphy [3] examined empirical studies (published between 20092013) to determine the themes in MOOC researches in two phases: "Connectivist MOOCs, Engagement and Creativity, 2009-2011" and "xMOOCs, Learning Analytics, Assessment and Critical Discourses about MOOCs, 2012-2013". The Ebben and Murphy study stated that themes in Phase One (2009-2011) dealt with the development of Connectivism theory and technological experimentation and innovation in cMOOCs. The Themes in Phase Two (2012-2013) dealt with the emergence of xMOOCs, the development of MOOC pedagogy and platforms, learning analytics and assessment, and a critical discourse about MOOCs. Gašević et al. [4] outlined the specific finding of an analysis of the research proposals submitted to the MOOC Research Initiative (MRI) funded by the Gates Foundation and administered by Athabasca University. They examined the main research themes and research methodologies used in the examined studies. Social learning was found as a theme that received the greatest interest and mixed methods was the most preferred research approach.

One year later, Raffaghelli et al. [9] explored the methodological approaches most commonly adopted in the scholarly literature about MOOCs published during the period January 2008-May 2014. According to these authors, studies have primarily focused on theoretical research and case studies. Other key findings included: surveys were the most presented data collection method and conceptualisation of dimensions were the most frequently used analysis method. The next year, Veletsianos and Shepherdson [6] reviewed 183 empirical MOOC papers published between 2013 and 2015 with a purpose to explore the geographical distribution, research components, article citations and research methodologies of MOOC studies published between 2013 and 2015. They founded that the majority of the examined studies is published by individuals who are from North America and Europe. In addition, the examined literature has favored a quantitative research method preferring the collection of data via surveys and automated methods. Recently, Zhu, Sari and Lee [10] published an article reviewing research methods and topics of 146 empirical studies of MOOCs (by searching the electronic database Scopus, and peer-reviewed journals) published from October 2014 to November 2016. This review indicated that most studies used quantitative research methods and the most frequently adopted data collection method was survey and descriptive statistics were the most adopted analysis method.

The examined reviews offer valuable syntheses required to understand trends related to MOOCs, but are partial. For instance, they fail to account for the distribution of research questions and frameworks adopted (and their cited authors) to answer these research questions. There is only a paucity of studies that presented clearly this as a main research question. Indeed, the first review is that of Kennedy [14] who conducted a review research in order to better understand the characteristics associated with MOOCs by reviewing six studies published in journals between 2009 and 2012. Specifically, this author examined the frameworks ground research in MOOCs, types of research methods that have been applied to MOOCs and the characteristics associated with MOOCs. The second review is that of Bozkurt et al. [22] who analyzed 51 theses and dissertations related to MOOCs and published between 2008 and 2015, identifying research trends and currents issues about MOOCs in terms of research methods, 
research themes, research models/designs, as well as theories, concepts, frameworks and models. Similar to this research, but with a different inclusion criterion (including only articles instead of theses), the third review of Bozkurt, Akgün-Özbek and Zawacki-Richter [23] reviewed 362 articles published from 2008 to 2015.

Thus, the purpose of the present review is to examine in depth these current trends and issues in research on MOOCs by reviewing recent research papers. More specifically, this literature review will attempt to respond to the following research questions:

1. What research issues or objectives have been analysed in the articles identified in this literature review?

2. What conceptual frameworks or theories have been adopted to respond to these different research questions?

3. What research methodologies have been adopted in terms of the collection, analysis, and processing of data?

\section{Methodology}

\subsection{Data collection method}

We collected data by using the scientific research method that identifies steps to conduct research literature review [24]. Only peer reviewed journals were retained for this study. Papers from report research, conference proceedings, books and thesis were not retained. A total of 36 high quality journals focusing on educational technology have been selected (Appendix A), of which 27 are indexed by the recognized databases (Scopus and Thomson Reuters). 5/27 of these journals tended to publish MOOC-related articles (i.e., Computers \& Education, British Journal of Educational Technology, International Review of Research in Open and Distributed Learning, Distance Education, and Internet and higher education).

The other 9 journals were included since they published MOOC related research such as "European Journal of Open, Distance and E-Learning" and "eLearning papers". The study had to be an empirical or review study. We excluded studies from the synthesis if they failed to provide precise research questions or objects of research and methodologies. Studies that are of engineering orientation which addressed topics such as software development or software engineers and platform development, conceptual papers, doctoral thesis and books were also excluded. We included articles according to three criteria:

1. Published between 1 January 2012 and 1 January 2018 .

2. Written in English or French;

3. Focused on MOOCs, so that the keywords MOOC (s) or Massive open online course (s) must be in the title or abstract. These inclusion criteria resulted in 100 research articles (77 empirical researches and 23 reviews) from 19 peer-reviewed journals (table 1). These 23 previous research reviews were also retained so as to provide some insights into the trends already observed in the literature. 
Table 1. Distribution of the 100 research articles (the other articles are presented in the appendix)

\begin{tabular}{|c|c|c|}
\hline Journal & $\begin{array}{l}\text { No. of } \\
\text { articles }\end{array}$ & Citations \\
\hline $\begin{array}{l}\text { American Educa- } \\
\text { tional Research } \\
\text { Journal }\end{array}$ & 1 & Greene, Oswald and Pomerantz [25] \\
\hline $\begin{array}{l}\text { American Journal of } \\
\text { Distance Education }\end{array}$ & 8 & $\begin{array}{l}\text { Arora, Goel, Sabitha and Mehrotra [26] ; Cohen and Magen-Nagar [27]; } \\
\text { Deshpande and Chukhlomin [28]; Gameel [29]; Liu, Kang et al.[30]; Liu, } \\
\text { McKelroy, EKang, Harron et Liu [31] ; Navarro [32]; Zutshi, O'Hare et } \\
\text { Rodafinos [33] }\end{array}$ \\
\hline $\begin{array}{l}\text { British Journal of } \\
\text { Educational Tech- } \\
\text { nology }\end{array}$ & 8 & $\begin{array}{l}\text { Chang, Hung and Lin [34] ; Hew [35]; Huisman, Admiraal, Pilli, van de } \\
\text { Ven et Saab [36]; Liyanagunawardena, Lundqvist et Williams [37] ; } \\
\text { Raffaghelli, Cucchiara and Persico [9]; Rieber [38]; Veletsianos, Collier } \\
\text { and Schneider [39]; Wang, Anderson, Chen et Barbera [40] }\end{array}$ \\
\hline $\begin{array}{l}\text { Computers \& Edu- } \\
\text { cation }\end{array}$ & 13 & $\begin{array}{l}\text { Almatrafi, Johri et Rangwala [41]; Chen and Chen [42]; } \\
\text { Davis, Chen, Hauffand et Houben [18]; Formanek, Wenger, Buxner, } \\
\text { Impey et Sonam [43] ; Hone and El Said [44]; Kizilcec, Pérez-Sanagustín } \\
\text { et Maldonado [45]; Paton, Fluck et Scanlan [17]; Phan, McNeil et Robin } \\
\text { [47]; Shapiro et al. [48]; Watson, Kim and Watson [49]; Watson, Watson, } \\
\text { Yu, Alamri, Mueller [50]; Zhang [51]; Zhou [52] }\end{array}$ \\
\hline Distance Education & 9 & $\begin{array}{l}\text { Adams, Yin, Vargas Madriz, et Mullen [53]; Andersen and Ponti [54]; } \\
\text { Ashton and Davies [55]; Evans and Myrick [56]; Firmin et al. [57]; } \\
\text { Henderikx, Kreijns et Kalz [58]; Li et al. [59]; Walji, Deacon, Small et } \\
\text { Czerniewicz [60]; Zhang, Skryabin et Song [61] }\end{array}$ \\
\hline $\begin{array}{l}\text { Educational Re- } \\
\text { searcher }\end{array}$ & 1 & Perna et al. [62] \\
\hline $\begin{array}{l}\text { Educational Tech- } \\
\text { nology Research } \\
\text { and Development }\end{array}$ & 5 & $\begin{array}{l}\text { Higashi, Schunn et Flot [63]; Loizzo and Ertmer [64]; } \\
\text { Watson, Loizzo, Watson, Mueller, Lim et Yang [65]; } \\
\text { Zhang et al. [66]; }\end{array}$ \\
\hline eLearning papers & 3 & Kennedy [14]; Martschink [67]; Yousef et al. [7] \\
\hline $\begin{array}{l}\text { Electronic Journal } \\
\text { of E-Learning }\end{array}$ & 1 & Admiraal, Huisman et Pilli [68] \\
\hline
\end{tabular}

The number of the founded articles for each journal is described in the table above. The table reveals that most articles were published in International Review of Research in Open and Distributed Learning $(n=27)$ followed by Computers \& Education $(n=13)$, Distance education $(n=9)$, American journal of Distance Education $(n=8)$, British Journal of Educational Technology $(n=8)$ and Internet and Higher Education $(n=8)$. The articles have been the subject of an in-depth analysis based on an analysis grid which facilitates the coding of data. The grid included both multiple-choice and open-ended questions and had three sections: writing characteristics (references, authors' description, authors disciplines, type of document, nature of document, the level of education under consideration); conceptual framework adopted (theoretical foundations, research concepts, questions or objectives); information on the empirical elements of the research (data collection method, data processing method and key findings). The grid was structured as reported in Table 2. 
Table 2. The elements of the analysis grid

\begin{tabular}{|c|c|c|}
\hline Section & Subsection & Item \\
\hline \multirow{5}{*}{$\begin{array}{l}\text { Writing characteris- } \\
\text { tics }\end{array}$} & References & $\begin{array}{l}\text { Author }(\mathrm{s}) \text { name }(\mathrm{s}), \text { title as published, journal title and } \\
\text { publication date }\end{array}$ \\
\hline & Affiliation of authors & Affiliation of the authors \\
\hline & Authors' discipline & $\begin{array}{l}\text { Range of disciplines: Didactics, Science Education, } \\
\text { Mathematic education, etc }\end{array}$ \\
\hline & Nature of document & Empirical or review study \\
\hline & School level considered & $\begin{array}{l}\text { School level considered. E.g.: primary school, secondary } \\
\text { school, high School academic (general), academic (pro- } \\
\text { fessional) }\end{array}$ \\
\hline \multirow{2}{*}{$\begin{array}{l}\text { Conceptual frame- } \\
\text { work adopted }\end{array}$} & $\begin{array}{l}\text { Conceptual framework } \\
\text { adopted (and main cited } \\
\text { authors) }\end{array}$ & $\begin{array}{l}\text { E.g.: Not stated explicitly stated through the text } \\
\text { and describe it if it is mentioned Mobilized concepts (the } \\
\text { definition adopted by the author and/or main attributes) }\end{array}$ \\
\hline & $\begin{array}{l}\text { Research question or } \\
\text { research object }\end{array}$ & $\begin{array}{l}\text { E.g.: Not stated explicitly stated through the text and } \\
\text { describe it if it is mentioned }\end{array}$ \\
\hline \multirow{5}{*}{$\begin{array}{l}\text { Methodology and } \\
\text { findings }\end{array}$} & $\begin{array}{l}\text { Description of the re- } \\
\text { search }\end{array}$ & Context and sample \\
\hline & Data collection method & $\begin{array}{l}\text { E.g.: surveys, interviews, data tracking for learning } \\
\text { analytics, virtual ethnography, etc. }\end{array}$ \\
\hline & Data analysis method & Qualitative, quantitative or mixed method \\
\hline & Treatment process & $\begin{array}{l}\text { E.g.: descriptive statistics, thematic analysis, inferential } \\
\text { statistics, etc. }\end{array}$ \\
\hline & Results & Summary of key findings \\
\hline
\end{tabular}

\subsection{Analysis method}

For the responses from the closed response questions presented in the grid, we used a descriptive statistic (E.g calculating the frequency of the distribution of data collection method, analysis method, etc). For the data issued from each open-ended question such as research question or goals, frameworks, we used a thematic content analysis technique. Indeed, the excerpts of the articles, in each item of the grid, were collected and read thoroughly in order to suggest thematic categories. These excerpts were divided into units of meaning (shorter segments of text that can be associated with a category). For instance, for the research that is questioning "What are the milestones that predict course completion? [62] was assigned to the category "predictors of retention", "What do key stakeholders (students, faculty, online support services, coordinators, and leaders) tell us they have learned from the AOLE experiment? [58]" was assigned to the category learning experience and finally this one "What kind of grading, if any, do professors utilize in MOOCs? [56]" was attributed to the thematic category design of MOOCs. We note that the categories must be explicit and mutually exclusive (each unit of meaning must only fall under one category) and they must make sense in terms of research in the field. 


\section{Results}

\subsection{Research questions or objectives}

We identified four categories of research objects in the 77 selected empirical articles: the learning process, predictors of retention, learning experiences and the design of MOOCs. We present below some of the results obtained. The learning process category is the most presented (38.96\%) followed by the design of MOOCs (23.38\%), learning experience $(20.78 \%)$ and predictors of retention (16.88\%) (figure 1).

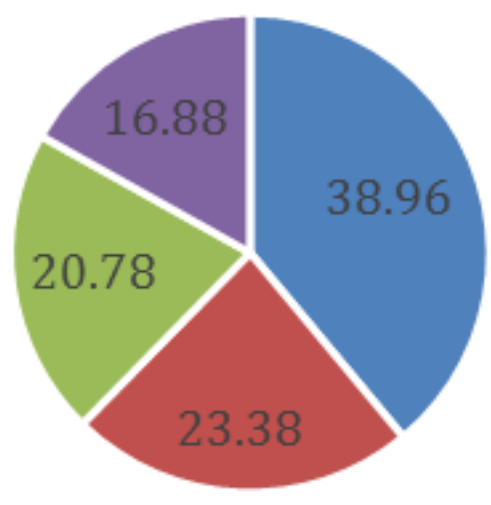

\section{- learning process}

- learning experience
- design of M0OCs - predictors of retention

Fig. 1. Distribution of research objects in MOOCs studies

The articles related to the learning process deal with determinants of learning and interactions in the MOOCs. The topics in these studies included how participants selfregulated their learning (6 studies), their motivations for participating or learning in a MOOC (5 studies), their behaviour in the course (4 studies) and the impact of educational and technical tools on learning (7 studies). The interaction in the MOOCs focused on the modes of interaction that characterised their participation in discussion forums ( 2 studies), the processes of interaction between users and organisers in the case of cMOOCs ( 1 study), the modes of communication privileged by learners ( 2 studies), the relationship between different levels of interaction or the participant behavior and modes of interaction ( 2 study) and their role in the co-construction of new knowledge (1 study).

The studies related to the predictors of retention of MOOC included analyzing the evolution of retention and/or participation of learners (1 study), typology for determining success and drop out in MOOCs (1 study), the impact of the learning strate- 
gies and motivation (6 studies) or the characteristic of learners (5 studies) on the level of success.

The topics of learning experience studies cover the perception of teaching, learning and design of MOOCs within MOOCs (12 study), the relationship between multiple learning styles and learner's intentions to use MOOCs (1 study) and the various difficulties encountered by students in MOOCs (3 studies).

The topics in studies related the design of MOOCs addressed efficiency of integration of MOOCs in traditional or classical teaching by examining the feasibility of using MOOCs as a learning environment with undergraduate students (2 studies), evaluation in MOOCs ( 5 studies), teaching methods adopted in MOOCs ( 7 studies) and the use of technological tools in MOOCs (4 studies). Indeed, the evaluation included research objects related to the types of evaluation proposed in MOOCs, the assessment by students of the effects of teaching and learning via a MOOC relevance of the content and the teaching methods. The 'teaching methods adopted in MOOCs' focused on analysing how instructors designed, developed and delivered MOOCs contents. Using technological tools in MOOCs' included research objects that focused on the methodological design of the MOOC, the identification of relevant post in the forum discussion and the access frequency of the elements of the platform.

\subsection{Conceptual frameworks}

To respond to the multiple research questions noted, the empirical studies undertaken adopted a variety of conceptual frameworks. Among the articles that have adopted these conceptual frameworks (42/77); 26 of these were explicitly presented and the other 16 were identifiable through the text. Interestingly, 35 papers out of 77 didn't employ any theoretical framework to respond to the research questions related to MOOCs, which equals to $45 \%$ of all the 77 empirical research. Table 3 shows that most of the research studies used one $(n=30)$ framework or theory. A minority of studies used two $(n=5)$, three $(n=1)$ and four frameworks or theories $(n=2)$. The conceptual frameworks refer mainly to learning theories such as self-regulation learning strategies and social learning ones $(n=13)$.

Table 3. Conceptual Frameworks (the other 31 frameworks are described in Appendix )

\begin{tabular}{|l|l|}
\hline \multicolumn{1}{|c|}{ Articles } & \multicolumn{1}{|c|}{ Conceptual framework or theories mobilised } \\
\hline Almatrafi et al. [41] & $\begin{array}{l}\text {-Model to identify "urgent" posts that need immediate attention from } \\
\text { instructors }\end{array}$ \\
\hline Chang et al. [34] & -The relationship between learning style and learning experience \\
\hline Hew [35] & $\begin{array}{l}\text {-Model of student engagement organized around the self- determination } \\
\text { theory of motivation (Appleton, Christenson and Furlong, 2008; } \\
\text { Fredricks, Blumenfeld, and Paris, 2004) }\end{array}$ \\
\hline Kahan, Soffer et Nachmias, [69] & -Holistic approach (Ferguson and Clow, 2015; Kizilcec et al., 2013) \\
\hline Kellogg, Booth et Oliver [70] & $\begin{array}{l}\text {-Connectivist learning theory (Siemens, 2005) } \\
\text {-Classification of the process of network formation (Rivera, } \\
\text { Soderstrom, and Uzzi, 2010) }\end{array}$ \\
\hline Koutropoulos et al. [71] & $\begin{array}{l}\text {-Framework of learner engagement (Henri, 1992) } \\
\text {-Social presence (De Wever et al. 2010) } \\
\text {-Social constructivism (Gunawardena, Carabajal, and Lower, 2001) }\end{array}$ \\
\hline
\end{tabular}




\begin{tabular}{|l|l|}
\hline & -Critical thinking (Webb, Newman, \& Cochrane, 1994) \\
\hline Perna [62] & $\begin{array}{l}\text {-Model of Ashby (2004) which differentiates the users according to the } \\
\text { date of registration and the manner of progression in a MOOC. }\end{array}$ \\
\hline Riyami, Mansouri and Poirier [72] & $\begin{array}{l}\text {-Framework of information and communication technologies for educa- } \\
\text { tion (ICTE) integration }\end{array}$ \\
\hline $\begin{array}{l}\text { Watson, Watson, Richardson et } \\
\text { Loizzo [73] }\end{array}$ & $\begin{array}{l}\text {-Community of Inquiry (Garrison, Anderson and Archer, 2000) and } \\
\text { dissonance theory (Kamradt and Kamradt, 1999; Simonson, 1979; } \\
\text { Simonson and Maushak, 1996) }\end{array}$ \\
\hline $\begin{array}{l}\text { Watson, Watson, Janakiraman et } \\
\text { Richardson [74] }\end{array}$ & $\begin{array}{l}\text {-Dissonance theory (Kamradt and Kamradt, 1999; Simonson, 1979; } \\
\text { Simonson \& Maushak 1996) } \\
\text {-CoI framework (Garrison, Anderson, \& Archer, 2000). }\end{array}$ \\
\hline Wise, Cui, Jin et Vytasek [75] & $\begin{array}{l}\text {-Framework for classifying MOOCs discussion forum posts (Stump et } \\
\text { al., 2013) }\end{array}$ \\
\hline
\end{tabular}

\subsection{Data collection and analysis methods}

Figure 2 shows the distribution of studies per each methodology. We can see that the most common research methodology type is quantitative method $(57,14 \%)$ followed by qualitative $(27,27 \%)$, and mixed method $(15,59 \%)$.

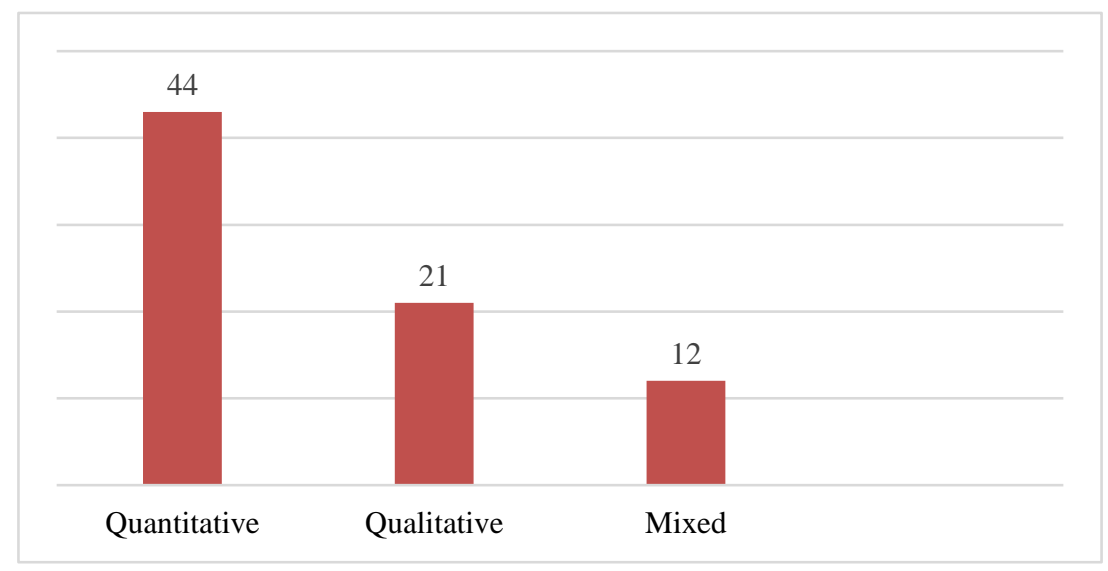

Fig. 2. Distribution of research methodologies in MOOCs studies

Findings concerning research methodologies used in MOOC research have a same trend compared to previous findings of the review conducted by Zhu et al. [10], who reported that most studies used quantitative research methods followed by mixed and qualitative research methods. The researchers largely focused on questionnaire/survey (43) (figure 2) which is in line with finding of the studies by Raffaghelli et al. [9] and Zhu et al. [10]. This collection tool is adopted by researchers to study the learners' activities and their experiences in MOOCs. The second largest collection method is data tracking for learning analytics (28) which is used to analyze co-creation of the content by the learners, the strategies adopted by MOOC instructors to teach contents and the interaction between participants in MOOCs. The third frequently used method 
is interview which is generally used to complete the questionnaire (21). Virtual ethnography (4) and narrative inquiry are the least frequent collection methods (1).

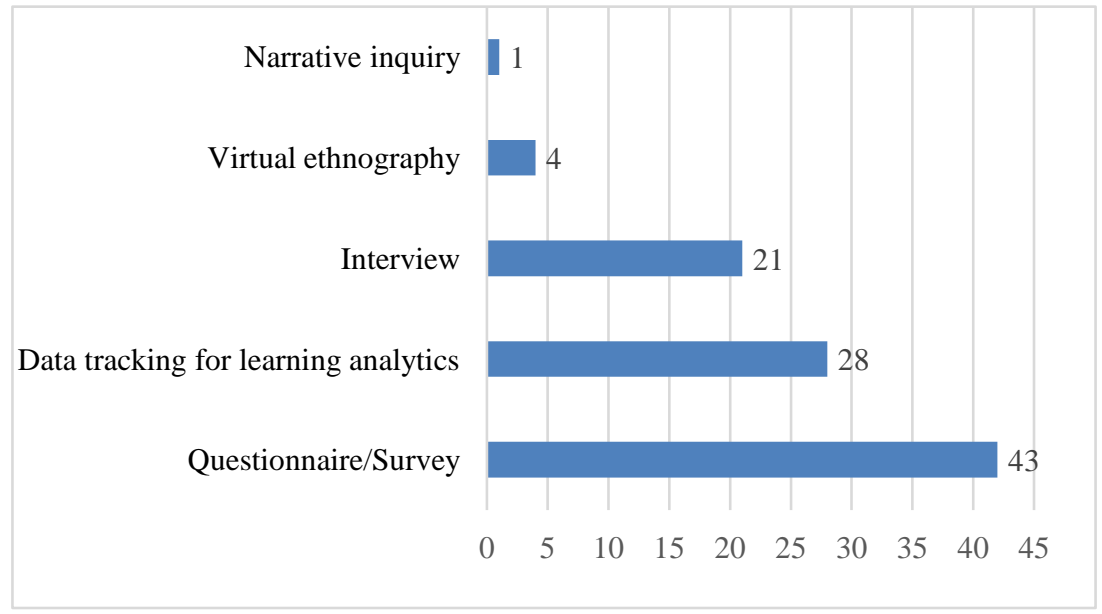

Fig. 3. Distribution of data collection methods in MOOCs studies

* One study may adopt more than one collection method. We note that learning analytics refer to the analysis and the reporting of data about learners and their contexts issued from SQL files, Quiz, Log files, discussion forum, etc.

Descriptive statistics were the most frequently used data processing method. Thematic/Discourse analysis was the second largest data processing. This result corresponds with findings in other studies. For instance, Veletsianos and Shepherdson [6] and Zhu et al. [10], stated that descriptive statistics were reported in almost all papers that they examined. Little use was observed in other methods (phenomenology, social network analysis, grounded theory, psychometric analysis and sentiment analysis).

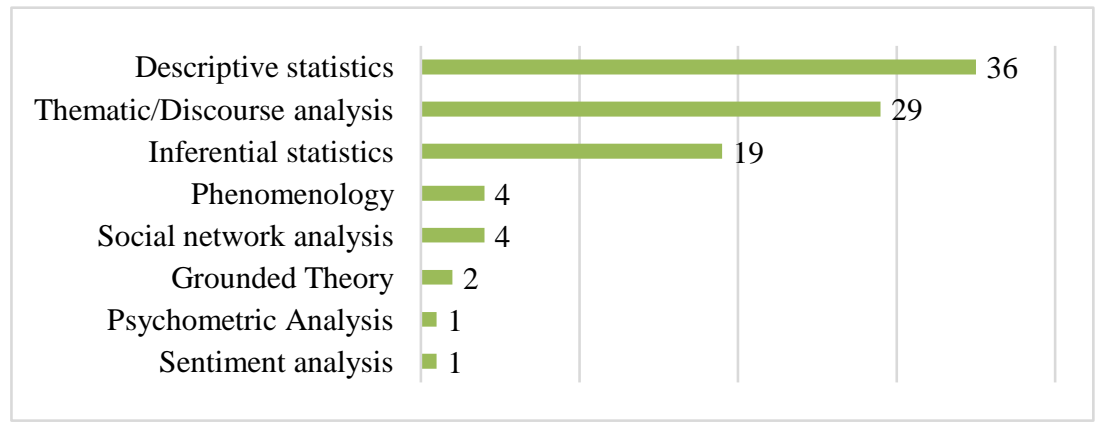

Fig. 4. Distribution of data analysis methods in MOOCs studies

*One study may adopt more than one treatment process 


\section{Discussion}

The 100 studies reveal interesting current trends related to the research on MOOCs published between January 2018 and January 2018 in peer-reviewed journals. These studies have been published in an assortment of peer-reviewed journals. Surprisingly, more than one-fourth of the research studies were published in International Review of Research in Open and Distributed Learning (IRRODL). Unlike the review of Raffaghelli et al. [9], literature reviews are quite present in this study (23 reviews). The findings of these 100 examined studies indicated that research questions have essentially focused on learning process $(38.96 \%)$ followed by the design of MOOCs (23.38\%), learning experience $(20.78 \%)$ and predictors of retention $(16.88 \%)$. More importantly, this result corresponds with findings of other studies. For instance, Raffaghelli et al. [9] stated that studies have focused on learning processes and pedagogical issues, impact of MOOCs on pedagogical theory and on educational institutions.

Although the conceptual frameworks used in the empirical studies vary widely, they have remained centred on learning issues. Learning processes were an important concern for researchers analysing MOOCs. This observation may be explained by the fact that given the open nature of a MOOC; researchers have focused on two phenomena. On the one hand, there is minimum direct interaction between instructors and learners, which forces learners to self-regulate their learning in MOOCs. On the other hand, interactions with peers with varying degrees of expertise, particularly in cMOOCs are centred on compensating for the inability to interact individually with instructors.

Although design of MOOCs is the second most frequent research question, a small number of studies assessing how learning occurs in MOOCs analysed the modalities and technologies used for assessment in MOOCs. Similarly, very few studies assessed the integration of MOOCs in traditional courses (blended MOOCs in a face-to-face environment). It is also worth mentioning that, as Veletsianos and Shepherdson [6] have noted, there is a paucity of studies examining content in relation to the experiences of teachers. As a result, future research can consider carrying MOOCs studies dealing with the manner in which MOOCs have been integrated in traditional courses and the difficulties experienced by teachers when offering, designing or teaching in MOOCs.

Results indicated also that most of the frameworks adopted in empirical researches generally have a focus on learning theories specifically self-regulated learning theories and social learning ones which is in line with findings of Bozkurt et al. [22], who stated that studies are framed by theories focusing on online learning communities and distance education learners. Although these frameworks are employed by many researchers to understand learning process within MOOC, they still centered on learners and they don't consider theoretical standpoints that are focused on knowledge which help researchers develop a deep understanding of the manner in which learners apprehend concepts. For instance, modeling the disciplinary structure of a content or the cognitive levels required to learn content through MOOC (what knowledge and competences are required to learn a specific discipline for example algorithmic, mathematics, etc.) (Svinicki, 2010) [76]. 
Finally, findings revealed that more than half of studies adopted quantitative methods and less than one sixth adopted mixed methods. As a result, surveys were the most used data collection method and descriptive statistics were the most adopted data analysis. This focus on quantitative research methods can be explained by the opportunities provided by platforms for researchers in order to easily access and study vast amounts of data [49].

\section{Conclusion and Implications for Future Research}

This study explored 100 studies published in peer reviewed journals between January 2012 and January 2018. The findings reveal that research questions have essentially focused on learning processes, design of MOOCs, learning experience and predictors of retention. The conceptual frameworks have focused on learning issues. Quantitative methods are predominant and the questionnaire is the preferred data collection tool. As a result, data processing has privileged descriptive statistics.

This synthesis reveals a number of implications for future research. Qualitative research focused on actual practices (based on ethnographic methods) may help promote a greater understanding of the learning experience of participants. This type of study may also help explain the integration/connection possibilities of MOOCs in traditional training trajectories. The follow-up of learners in these open and massive training systems benefits today from the development of tools and methods for systematic text mining, automatic language processing and recommendations generation combining user profiles, content descriptions, classification, filtering, trace analysis and so on. Consequently, a thorough study of leaning analytics deserves a particular attention in future research. Using theoretical frameworks focusing on knowledge by researchers, may help define the learning process and the factors that influence it and determine the difficulties experienced by participants when learning specific concepts. By addressing these challenges, instructional designers could improve the design of MOOCs. 


\section{References}

[1] Budiman, R. (2013). Utilizing Skype for providing learning support for Indonesian distance learning students: A lesson learnt. Procedia - Social and Behavioral Sciences, 83: 510. https://doi.org/10.1016/j.sbspro.2013.06.002

[2] Baturay, M. H. (2015) 'An overview of the world of MOOCs', Procedia-Social and Behavioral Sciences, Vol. 174, pp.427-433. https://doi.org/10.1016/j.sbspro.2015.01.685

[3] Ebben, M. and Murphy, J. S. (2014) 'Unpacking MOOC scholarly discourse: a review of nascent MOOC scholarship', Learning, Media and Technology, Vol. 39 No. 3, pp.328345. https://doi.org/10.1080/17439884.2013.878352

[4] Gasevic, D., Kovanovic, V., Joksimovic, S. and Siemens, G. (2014) 'Where is research on massive open online courses headed? A data analysis of the MOOC Research Initiative', The International Review of Research in Open and Distributed Learning, Vol. 15 No. 5, pp.135-176. https://doi.org/10.19173/irrodl.v15i5.1954

[5] Liyanagunawardena, T. R., Adams, A. A. and Williams, S. A. (2013) 'MOOCs: A systematic study of the published literature 2008-2012', The International Review of Research in Open and Distributed Learning, Vol. 14 No. 3, pp.202-227. https://doi.org/10. 19173/irrodl.v14i3.1455

[6] Veletsianos, G. and Shepherdson, P. (2016) 'A systematic analysis and synthesis of the empirical MOOC literature published in 2013-2015', The International Review of Research in Open and Distributed Learning, Vol. 17 No. 2, pp.199-221. https://doi.org/10. 19173/irrodl.v17i2.2448

[7] Yousef, A. M. F., Chatti, M. A., Schroeder, U., Wosnitza, M. and Jakobs, H. (2014), 'A Review of the State-of-the-Art', Proceedings of the 6th International Conference on Computer Supported Education

[8] Zawacki-Richter, O., Bozkurt, A., Alturki, U. and Aldraiweesh, A. (2018) 'What Research Says About MOOCs-An Explorative Content Analysis', The International Review of Research in Open and Distributed Learning, Vol. 19 No. 1, pp.243-259. https://doi.org/10. 19173/irrodl.v19i1.3356

[9] Raffaghelli, J. E., Cucchiara, S. and Persico, D. (2015) 'Methodological approaches in MOOC research: Retracing the myth of Proteus', British Journal of Educational Technology, Vol. 46 No. 3, pp.488-509. https://doi.org/10.1111/bjet.12279

[10] Zhu, M., Sari, A. and Lee, M. M. (2018) 'A systematic review of research methods and topics of the empirical MOOC literature (2014-2016)', The Internet and Higher Education, Vol. 37, pp. 31-39. https://doi.org/10.1016/j.iheduc.2018.01.002

[11] Chen, Y. (2014) 'Investigating MOOCs through blog mining, The International Review of Research in Open and Distributed Learning, Vol. 215 No. 2, pp. 86-106. https://doi.org/ 10.19173/irrodl.v15i2.1695

[12] Jordan, K. (2014) 'Initial trends in enrolment and completion of massive open online courses', The International Review of Research in Open and Distributed Learning, 15(1). https://doi.org/10.19173/irrodl.v15i1.1651

[13] Joksimović, S., et al. (2018) 'How do we model learning at scale? A systematic review of research on MOOCs', Review of Educational Research, Vol.88 No. 1.

[14] Kennedy, J. (2014) 'Characteristics of massive open online courses (MOOCs): A research review, 2009-2012', Journal of Interactive Online Learning, Vol. 13 No. 1

[15] Lee, D., Watson, S. L. and Watson, W. R. (2019) 'Systematic literature review on selfregulated learning in massive open online courses', Australasian Journal of Educational Technology, Vol. 35 No. 1, pp.28-41. https://doi.org/10.14742/ajet.3749 
[16] Nortvig, A. M. and Christiansen, R. B. (2017) 'Institutional Collaboration on MOOCs in Education-A Literature Review', The International Review of Research in Open and Distributed Learning, Vol. 18 No. 6, pp.307-316. https://doi.org/10.19173/irrodl.v18i6.311 $\underline{0}$

[17] Paton, R. M., Fluck, A. E. and Scanlan, J. D. (2018) 'Engagement and retention in VET MOOCs and online courses: A systematic review of literature from 2013-2017', Computers \& Education, Vol. 125, pp. 191-201. https://doi.org/10.1016/j.compedu.2018. $\underline{06.013}$

[18] Davis, D., Chen, G., Hauff, C., \& Houben, G. J. (2018). Activating learning at scale: A review of innovations in online learning strategies. Computers \& Education, 125, 327-344. https://doi.org/10.1016/j.compedu.2018.05.019

[19] Rolfe, V. (2015) 'A systematic review of the socio- aspects of Massive Online Open Courses', European Journal of Open, Distance and E-Learning, Vol. 18 No. 1, pp.52-71. https://doi.org/10.1515/eurodl-2015-0004

[20] Israel, M. J. (2015) 'Effectiveness of integrating MOOCs in traditional classrooms for undergraduate students', The International Review of Research in Open and Distributed Learning, Vol. 16 No. 5, pp.102-118, https://doi.org/10.19173/irrodl.v16i5.2222

[21] Veletsianos, G. and Shepherdson, P. (2015) 'Who studies MOOCs? Interdisciplinarity in MOOC research and its changes over time', The International Review of Research in Open and Distributed Learning, Vol. 16 No. 3, pp.1-17. https://doi.org/10.19173/irrodl.v16i3.22 $\underline{02}$

[22] Bozkurt, A., Keskin, N. O., \& de Waard, I. (2016). Research trends in massive open online course (MOOC) theses and dissertations: Surfing the tsunami wave. Open Praxis, 8(3), 203-221. https://doi.org/10.5944/openpraxis.8.3.287

[23] Bozkurt, A., Akgün-Özbek, E. and Zawacki-Richter, O. (2017) 'Trends and patterns in massive open online courses: Review and content analysis of research on MOOCs', The International Review of Research in Open and Distributed Learning, Vol. 18 No. 5, pp.119-147. https://doi.org/10.19173/irrodl.v18i5.3080

[24] Fink, A. (2005) 'Conducting research literature reviews: From the internet to paper'

[25] Greene, J. A., Oswald, C. A. and Pomerantz, J. (2015) 'Predictors of retention and achievement in a massive open online course', American Educational Research Journal, Vol. 52 No. 5, pp. 925-955. https://doi.org/10.3102/0002831215584621

[26] Arora, S., Goel, M., Sabitha, A. S. and Mehrotra, D. (2017) 'Learner groups in massive open online courses', American Journal of Distance Education, Vol. 31 No. 2, pp.80-97. https://doi.org/10.1080/08923647.2017.1300461

[27] Cohen, L. and Magen-Nagar, N. (2016) 'Self-Regulated Learning and a Sense of Achievement in MOOCs Among High School Science and Technology Students', American Journal of Distance Education, Vol. 30 No. 2, pp.68-79. https://doi.org/10.1080/ $\underline{08923647.2016 .1155905}$

[28] Deshpande, A., \& Chukhlomin, V. (2017). What makes a good MOOC: A field study of factors impacting student motivation to learn. American Journal of Distance Education, 31(4), 275-293. https://doi.org/10.1080/08923647.2017.1377513

[29] Gameel, B. G. (2017) 'Learner satisfaction with massive open online courses', American Journal of Distance Education, Vol. 31 No. 2, pp. 98-111. https://doi.org/10.1080/0892364 7.2017.1300462

[30] Liu, M., Kang, J., Cao, M., Lim, M., Ko, Y., Myers, R. and Schmitz Weiss, A. (2014) 'Understanding MOOCs as an emerging online learning tool: Perspectives from the students', American Journal of Distance Education, Vol. 28 No. 3, pp.147-159. https://doi. org/10.1080/08923647.2014.926145 
[31] Liu, M., McKelroy, E., Kang, J., Harron, J. and Liu, S. (2016) 'Examining the Use of Facebook and Twitter as an Additional Social Space in a MOOC', American Journal of Distance Education, Vol. 30 No. 1, pp.14-26. https://doi.org/10.1080/08923647.2016.1120 $\underline{584}$

[32] Navarro, P. (2015). The Death of the Large Lecture Hall, the Rise of Peer-to-Peer Course Delivery?. American Journal of Distance Education, 29(4), 260-268. https://doi.org/10.10 80/08923647.2015.1084837

[33] Zutshi, S., O'Hare, S. and Rodafinos, A. (2013) 'Experiences in MOOCs: The perspective of students', American Journal of Distance Education, Vol. 27 No. 4, pp.218-227. https:// doi.org/10.1080/08923647.2013.838067

[34] Chang, R. I., Hung, Y. H. and Lin, C. F. (2015) 'Survey of learning experiences and influence of learning style preferences on user intentions regarding MOOCs', British Journal of Educational Technology, Vol. 46 No. 3, pp. 528-541. https://doi.org/10.1111/bjet.12275

[35] Hew, K. F. (2016) 'Promoting engagement in online courses: What strategies can we learn from three highly rated MOOCS', British Journal of Educational Technology, Vol. 47 No. 2, pp. 320-341. https://doi.org/10.1111/bjet.12235

[36] Huisman, B., Admiraal, W., Pilli, O., van de Ven, M. and Saab, N. (2018) 'Peer assessment in MOOCs: The relationship between peer reviewers' ability and authors' essay performance', British Journal of Educational Technology, Vol; 49 No. 1, pp.101-110. https://doi.org/10.1111/bjet.12520

[37] Liyanagunawardena, T. R., Lundqvist, K. Ø. and Williams, S. A. (2015) 'Who are with us: MOOC learners on a FutureLearncourse', British Journal of Educational Technology, Vol. 46 No. 3, pp.557-569. https://doi.org/10.1111/bjet.12261

[38] Rieber, L. P. (2017) 'Participation patterns in a massive open online course (MOOC) about statistics', British Journal of Educational Technology, Vol. 48 No. 6, pp.1295-1304. https ://doi.org/10.1111/bjet.12504

[39] Veletsianos, G., Collier, A. and Schneider, E. (2015) 'Digging deeper into learners' experiences in MOOC s: participation in social networks outside of MOOC s, notetaking and contexts surrounding content consumption', British Journal of Educational Technology, Vol. 46 No. 3, pp.570-587. https://doi.org/10.1111/bjet.12297

[40] Wang, Z., Anderson, T., Chen, L., \& Barbera, E. (2016). Interaction pattern analysis in cMOOCs based on the connectivist interaction and engagement framework. British Journal of Educational Technology, 48(2), 683-699. doi: 10.1111/bjet.12433. https://doi. org/10.1111/bjet.12433

[41] Almatrafi, O., Johri, A. and Rangwala, H. (2018) 'Needle in a haystack: Identifying learner posts that require urgent response in MOOC discussion forums', Computers \& Education, Vol. 118, pp. 1-9. https://doi.org/10.1016/j.compedu.2017.11.002

[42] Chen, Y. H. and Chen, P. J. (2015) 'MOOC study group: Facilitation strategies, influential factors, and student perceived gains', Computers \& Education, Vol.86, pp. 55-70. https:// doi.org/10.1016/i.compedu.2015.03.008

[43] Formanek, M., Wenger, M. C., Buxner, S. R., Impey, C. D. and Sonam, T. (2017) 'Insights about large-scale online peer assessment from an analysis of an astronomy MOOC', Computers \& Education, pp.113, 243-262. https://doi.org/10.1016/j.compedu.2017.05.019

[44] Hone, K. S. and El Said, G. R. (2016) 'Exploring the factors affecting MOOC retention: A survey study', Computers \& Education, Vol.98, pp.157-168. https://doi.org/10.1016/j.co mpedu.2016.03.016

[45] Kizilcec, R. F., Pérez-Sanagustín, M., \& Maldonado, J. J. (2017). Self-regulated learning strategies predict learner behavior and goal attainment in Massive Open Online Courses. Computers \& education, 104, 18-33. https://doi.org/10.1016/j.compedu.2016.10.001 
[46] Phan, T., McNeil, S. G. and Robin, B. R. (2016) 'Students' patterns of engagement and course performance in a Massive Open Online Course', Computers \& Education, Vol. 95, pp.36-44. https://doi.org/10.1016/j.compedu.2015.11.015

[47] Shapiro, H. B., Lee, C. H., Roth, N. E. W., Li, K., Çetinkaya-Rundel, M. and Canelas, D. A. (2017) 'Understanding the massive open online course (MOOC) student experience: An examination of attitudes, motivations, and barriers', Computers \& Education, Vol. 110, pp.35-50. https://doi.org/10.1016/j.compedu.2017.03.003

[48] Watson, W. R., Kim, W. and Watson, S. L. (2016) 'Learning outcomes of a MOOC designed for attitudinal change: A case study of an Animal Behavior and Welfare MOOC', Computers \& Education, Vol. 96, pp.83-93. https://doi.org/10.1016/j.compedu.2016.01.01 $\underline{3}$

[49] Watson, S. L., Watson, W. R., Yu, J. H., Alamri, H. and Mueller, C. (2017) 'Learner profiles of attitudinal learning in a MOOC: An explanatory sequential mixed methods study', Computers \& Education, Vol. 114, pp.274-285. https://doi.org/10.1016/j.compedu. 2017.07.005

[50] Zhang, J. (2016) 'Can MOOCs be interesting to students? An experimental investigation from regulatory focus perspective', Computers \& Education, Vol. 95, pp.340-351. https:// doi.org/10.1016/j.compedu.2016.02.003

[51] Zhou, M. (2016). Chinese university students' acceptance of MOOCs: A self-determination perspective. Computers \& Education, 92, 194-203. https://doi.org/10.1016/j.compedu.20 $\underline{15.10 .012}$

[52] Adams, C., Yin, Y., 'Vargas Madriz, L. F., \& Mullen, C. S. (2014) 'A phenomenology of learning large: the tutorial sphere of XMOOC video lectures', Distance Education, Vol. 35 No.1, pp.202 - 216. https://doi.org/10.1080/01587919.2014.917701

[53] Andersen, R. and Ponti, M. (2014) 'Participatory pedagogy in an open educational course: challenges and opportunities', Distance Education, Vol. 35 No. 2, pp.234-249. https://doi. org/10.1080/01587919.2014.917703

[54] Ashton, S. and Davies, R. S. (2015) 'Using scaffolded rubrics to improve peer assessment in a MOOC writing course', Distance Education, Vol. 36 No. 3, pp.312-334. https://doi. org/10.1080/01587919.2015.1081733

[55] Evans, S. and Myrick, J. G. (2015) 'How MOOC instructors view the pedagogy and purposes of massive open online courses', Distance Education, Vol. 36 No. 3, pp. 295-311. https://doi.org/10.1080/01587919.2015.1081736

[56] Firmin, R., Schiorring, E., Whitmer, J., Willett, T., Collins, E. D. and Sujitparapitaya, S. (2014) 'Case study: Using MOOCs for conventional college coursework', Distance Education, Vol. 35 No. 2, pp.178-201. https://doi.org/10.1080/01587919.2014.917707

[57] Henderikx, M. A., Kreijns, K. and Kalz, M. (2017) 'Refining success and dropout in massive open online courses based on the intention-behavior gap', Distance Education, Vol. 38 No. https://doi.org/10.1080/01587919.2017.1369006

[58] Li, N., Verma, H., Skevi, A., Zufferey, G., Blom, J. and Dillenbourg, P. (2014) 'Watching MOOCs together: Investigating co-located MOOC study groups', Distance Education, Vol. 35 No. 2, pp.217-233. https://doi.org/10.1080/01587919.2014.917708

[59] Walji, S., Deacon, A., Small, J. and Czerniewicz, L. (2016) 'Learning through engagement: MOOCs as an emergent form of provision', Distance Education, Vol. 37 No. 2, pp.208-223. https://doi.org/10.1080/01587919.2016.1184400

[60] Zhang, J., Skryabin, M. and Song, X. (2016) 'Understanding the dynamics of MOOC discussion forums with simulation investigation for empirical network analysis (SIENA)', Distance Education, Vol. 37 No. 3, pp.270-286. https://doi.org/10.1080/01587919.2016.12 $\underline{26230}$ 
[61] Perna, L. W., Ruby, A., Boruch, R. F., Wang, N., Scull, J., Ahmad, S. and Evans, C. (2014) 'Moving through MOOCs: Understanding the progression of users in massive open online courses', Educational Researcher, Vol. 43 No. 9, pp.421-432. https://doi.org/10.310 2/0013189x14562423

[62] Higashi, R. M., Schunn, C. D. and Flot, J. B. (2017) 'Different underlying motivations and abilities predict student versus teacher persistence in an online course', Educational Technology Research and Development, Vol. 65 No. 6, pp.1471-1493. https://doi.org/10. 1007/s11423-017-9528-Z

[63] Loizzo, J. and Ertmer, P. A. (2016) 'MOOCocracy: the learning culture of massive open online courses', Educational Technology Research and Development, Vol. 64 No. 6, pp.1013-1032. https://doi.org/10.1007/s11423-016-9444-7

[64] Watson, S. L., Loizzo, J., Watson, W. R., Mueller, C., Lim, J. and Ertmer, P. A. (2016) 'Instructional design, facilitation, and perceived learning outcomes: an exploratory case study of a human trafficking MOOC for attitudinal change', Educational Technology Research and Development, Vol. 64. No. 6, pp.1273-1300. https://doi.org/10.1007/s11423016-9457-2

[65] Zhang, Q., Peck, K. L., Hristova, A., Jablokow, K. W., Hoffman, V., Park, E. and Bayeck, R. Y. (2016) 'Exploring the communication preferences of MOOC learners and the value of preference-based groups: Is grouping enough?', Educational Technology Research and Development, Vol. 64 No. 4, pp.809-837. https://doi.org/10.1007/s11423-016-9439-4

[66] Martschink, B. (2014) 'Mathematics courses: Fostering individuality through EMOOCs', eLearning Papers, Vol. 37, pp.71-78

[67] Admiraal, W., Huisman, B. and Pilli, O. (2015) 'Assessment in Massive Open Online Courses', Electronic Journal of e-Learning, Vol. 13 No.4, pp.207-216

[68] Kahan, T., Soffer, T. and Nachmias, R. (2017) 'Types of Participant Behavior in a Massive Open Online Course', The International Review of Research in Open and Distributed Learning, Vol. 18 No. 6, pp.2-18. https://doi.org/10.19173/irrodl.v18i6.3087

[69] Kellogg, S., Booth, S. and Oliver, K. (2014) 'A social network perspective on peer supported learning in MOOCs for educators', The International Review of Research in Open and Distributed Learning, Vol. 15 No. 5, pp.264-289. https://doi.org/10.19173/irrodl. v15i5.1852

[70] Koutropoulos, A., Gallagher, M. S., Abajian, S. C., de Waard, I., Hogue, R. J., Keskin, N. Ö. and Rodriguez, C. O. (2012) 'Emotive vocabulary in MOOCs: Context \& participant retention', European Journal of Open, Distance and E-Learning, Vol. 15 No. 1

[71] Riyami, B., Mansouri, K. and Poirier, F. (2019) 'Contribution to the multidimensional analysis of the success factors of the integration of the ICTE in higher education in Morocco: case of the MOOC'relational databases: understanding to master'students' point of view', International Journal of Technology Enhanced Learning, Vol. 11 No. 1, pp.80-102. https://doi.org/10.1504/ijtel.2019.096750

[72] Watson, S. L., Watson, W. R., Richardson, J. and Loizzo, J. (2016) 'Instructor's use of social presence, teaching presence, and attitudinal dissonance: A case study of an attitudinal change MOOC', The International Review of Research in Open and Distributed Learning, Vol. 17 No. 3, pp.55-74. https://doi.org/10.19173/irrodl.v17i3.2379

[73] Watson, S. L., Watson, W. R., Janakiraman, S. and Richardson, J. (2017) 'A team of instructors' use of social presence, teaching presence, and attitudinal dissonance strategies: An animal behaviour and welfare MOOC', The International Review of Research in Open and Distributed Learning, Vol. 18 No. 2, pp.69-91. https://doi.org/10.19173/irrodl.v18i2.26 $\underline{63}$ 
[74] Wise, A. F., Cui, Y., Jin, W. and Vytasek, J. (2017) 'Mining for gold: Identifying contentrelated MOOC discussion threads across domains through linguistic modeling', The Internet and Higher Education, Vol. 32, pp.11-28. https://doi.org/10.1016/j.heduc.2016.0 $\underline{8.001}$

[75] Svinicki, M. D. 2010. A guidebook on conceptual frameworks for research in engineering education. Rigorous Research in Engineering Education, pp.1-53

[76] Cheng, J. C. (2014) 'An exploratory study of emotional affordance of a massive open online course', European Journal of Open, Distance and E-learning, Vol. 17 No. 1, pp.4355. https://doi.org/10.2478/eurodl-2014-0003

[77] Kop, R. and Carroll, F. (2011) 'Cloud computing and creativity: Learning on a massive open online course', European Journal of Open, Distance and E-learning, Vol. 14 No. 2

[78] Poce, A. (2015) 'Developing critical perspectives on technology in education: A tool for MOOC evaluation', European Journal of Open, Distance and E-learning, Vol. 18 No.1

[79] Pundak, D., Sabag, N. and Trotskovsky, E. (2014) 'Accreditation of MOOCs', European Journal of Open, Distance and E-learning, Vol. 17 No. 2, pp.117-129. https://doi.org/10.24 78/eurodl-2014-0023

[80] Weller, M. and Anderson, T. (2013) 'Digital resilience in higher education', European Journal of Open, Distance and E-learning, Vol. 16 No. 1, pp.53-66

[81] Jézégou, A. (2015) 'Diriger soi-même ses activités d'apprentissage par et dans un Mooc de type connectiviste', International Journal of E-Learning \& Distance Education, Vol. 30 No. 1

[82] Temperman, G., De Lièvre, B. and De Stercke, J. (2016) 'Activity dashboard, time management, self-regulation and efficiency in a CSCL environment', International Journal of E-Learning \& Distance Education, Vol. 31 No. 1, pp.2-11

[83] Sanchez-Gordon, S. and Luján-Mora, S. (2017) 'Research challenges in accessible MOOCs: a systematic literature review 2008-2016, Universal Access in the Information Society, pp.1-15. https://doi.org/10.1007/s10209-017-0531-2

[84] Alario-Hoyos, C., Estévez-Ayres, I., Pérez-Sanagustín, M., Kloos, C. D. and FernándezPanadero, C. (2017) 'Understanding learners' motivation and learning strategies in MOOCs', The International Review of Research in Open and Distributed Learning, Vol. 8 No.3, pp.120-137. https://doi.org/10.19173/irrodl.v18i3.2996

[85] Cho, M. H. and Byun, M. K. (2017) 'Nonnative English-Speaking Students' Lived Learning Experiences With MOOCs in a Regular College Classroom', The International Review of Research in Open and Distributed Learning, Vol. 18 No. 5, pp.174-190. https:// doi.org/10.19173/irrodl.v18i5.2892

[86] Costley, J. and Lange, C. H. (2017) 'The effects of lecture diversity on germane load', The International Review of Research in Open and Distributed Learning, Vol. 18 No. 2. https:// doi.org/10.19173/irrodl.v18i2.2860

[87] de Lima, M. and Zorrilla, M. E. (2017) 'Social Networks and the Building of Learning Communities: An Experimental Study of a Social MOOC', The International Review of Research in Open and Distributed Learning, Vol. 18 No. 1, pp. 40-64. https://doi.org/10.19 173/irrodl.v18i1.2630

[88] Engle, D., Mankoff, C. and Carbrey, J. (2015) 'Coursera's introductory human physiology course: Factors that characterize successful completion of a MOOC', The International Review of Research in Open and Distributed Learning, Vol. 16 No. 2, pp.46-68. https:// doi.org/10.19173/irrodl.v16i2.2010

[89] Gil-Jaurena, I., Callejo-Gallego, J. and Agudo, Y. (2017) 'Evaluation of the UNED MOOCs implementation: demographics, learners' opinions and completion rates', The In- 
ternational Review of Research in Open and Distributed Learning, Vol 18 No. 7, pp.142168. https://doi.org/10.19173/irrodl.v18i7.3155

[90] Jiang, S., Williams, A. E., Warschauer, M., He, W. and O'Dowd, D. K. (2014). Influence of incentives on performance in a pre-college biology MOOC, The International Review of Research in Open and Distributed Learning, Vol. 15 No. 5, pp.100-112. https://doi.org/10. 19173/irrodl.v15i5.1858

[91] Kwak, S. (2017) 'Approaches Reflected in Academic Writing MOOCs', The International Review of Research in Open and Distributed Learning, Vol. 18 No. 3, pp.139-155. https:// doi.org/10.19173/irrodl.v18i3.2845

[92] Najafi, H., Rolheiser, C., Harrison, L. and Håklev, S. (2015) 'University of Toronto instructors' experiences with developing MOOCs', The International Review of Research in Open and Distributed Learning, Vol. 16 No. 3, pp.233-255. https://doi.org/10.19173/irrodl. $\underline{v 16 i 3.2073}$

[93] Rohs, M. and Ganz, M. (2015) 'MOOCs and the claim of education for all: A disillusion by empirical data', The International Review of Research in Open and Distributed Learning, Vol. 16 No. 6, pp. 1-19. https://doi.org/10.19173/irrodl.v16i6.2033

[94] Soffer, T. and Cohen, A. (2015) 'Implementation of Tel Aviv university MOOCs in academic curriculum: A pilot study', The International Review of Research in Open and Distributed Learning, Vol. 16 No. 1, pp.80-97. https://doi.org/10.19173/irrodl.v16i1.2031

[95] Yang, H. H., \& Su, C. H. (2017) 'Learner Behaviour in a MOOC Practice-oriented Course: In Empirical Study Integrating TAM and TPB', The International Review of Research in Open and Distributed Learning, Vol. 18 No. 5, pp.36-63. https://doi.org/10.19173/irrodl. v18i5.2991

[96] Zawacki-Richter, O., Bozkurt, A., Alturki, U., \&Aldraiweesh, A. (2018). What Research Says About MOOCs-An Explorative Content Analysis. The International Review of Research in Open and Distributed Learning, 19(1), 243-259. https://doi.org/10.19173/irro dl.v19i1.3356

[97] Milligan, C., \& Littlejohn, A. (2017). Why study on a MOOC? The motives of students and professionals. The International Review of Research in Open and Distributed Learning, 18(2). https://doi.org/10.19173/irrodl.v18i2.3033

[98] Gillani, N. and Eynon, R. (2014) 'Communication patterns in massively open online courses', The Internet and Higher Education, Vol. 23, pp.18-26. https://doi.org/10.1016/j. iheduc.2014.05.004

[99] Littlejohn, A., Hood, N., Milligan, C. and Mustain, P. (2016) 'Learning in MOOCs: Moti vations and self-regulated learning in MOOCs', The Internet and Higher Education, Vol. 29, pp.40-48. https://doi.org/10.1016/j.iheduc.2015.12.003

[100] Milligan, C. and Littlejohn, A. (2016) 'How health professionals regulate their learning in massive open online courses', The Internet and Higher Education, Vol. 31, pp.113-121. https://doi.org/10.1016/j.iheduc.2016.07.005

[101] Stich, A. E. and Reeves, T. D. (2017) 'Massive open online courses and underserved students in the United States', The Internet and Higher Education, Vol. 32, pp.58-71. https ://doi.org/10.1016/j.iheduc.2016.09.001

[102] Toven-Lindsey, B., Rhoads, R. A. and Lozano, J. B. (2015) 'Virtually unlimited classrooms: pedagogical practices in massive open online courses', The internet and higher education, Vol. 24, pp.1-12. https://doi.org/10.1016/j.iheduc.2014.07.001

[103] Watted, A. and Barak, M. (2018) 'Motivating factors of MOOC completers: Comparing between university-affiliated students and general participants' The Internet and Higher Education, Vol. 37, pp.11-20. https://doi.org/10.1016/j.iheduc.2017.12.001 
[104] Hew, K. F. and Cheung, W. S. (2014) 'Students' and instructors use of massive open online courses (MOOCs): Motivations and challenges', Educational research review, Vol. 12, pp.45-58. https://doi.org/10.1016/j.edurev.2014.05.001

[105] Jacoby, J. (2014). The disruptive potential of the Massive Open Online Course: A literature review. Journal of Open, Flexible and Distance Learning, 18(1), 73-85. Retrieved from: http://www.jofdl.nz/

\section{$7 \quad$ Author}

Abdelghani Babori is a doctor in cotutelle between the University Hassan 1st , Faculty of Sciences \& Technology Settat Morocco and the University of Lille, Doctoral School for the Humanities and Social Sciences France. He got his special higher studies degree in software engineering from National School of Applied Sciences in 2014. His area of interest includes teaching algorithmic and programming, educational technologies, eLearning, didactics, education.

Article submitted 2020-04-05. Resubmitted 2020-05-25. Final acceptance 2020-05-27. Final version published as submitted by the authors.

\section{$8 \quad$ Appendix}

Table 4. Distribution of the 100 research articles (continued)

\begin{tabular}{|l|c|l|}
\hline \multicolumn{1}{|c|}{ Section } & Subsection & \multicolumn{1}{|c|}{ Item } \\
\hline $\begin{array}{l}\text { European Journal of Open, Distance } \\
\text { and E-Learning }\end{array}$ & 7 & $\begin{array}{l}\text { Cheng [77]; Kop and Carroll [78]; Koutropoulos et al. } \\
\text { [71]; Poce [79]; Pundak, Sabag et Trotskovsky [80]; } \\
\text { Rolfe [19]; Weller and Anderson [81]; }\end{array}$ \\
\hline $\begin{array}{l}\text { International Journal of E-Learning } \\
\text { \& Distance Education }\end{array}$ & 2 & Jézégou [82]; Temperman et al. [83]; \\
\hline $\begin{array}{l}\text { Learning, Media and Technology } \\
\text { Enternational Journal of Technology }\end{array}$ & 1 & Ebben and Murphy [3] \\
\hline $\begin{array}{l}\text { Universal Access in the Information } \\
\text { Society }\end{array}$ & 1 & Riyami, Mansouri and Poirier [72] \\
\hline Sanchez-Gordon and Luján-Mora [84]
\end{tabular}




\begin{tabular}{|l|c|l|}
\hline The Internet and Higher Education & 8 & $\begin{array}{l}\text { Gillani and Eynon [99]; Littlejohn, Hood, Milligan et } \\
\text { Mustain [100]; Milligan, and Littlejohn [101]; Stich and } \\
\text { Reeve [102]; Toven-Lindsey, Rhoads et Lozano [103]; } \\
\text { Watted and Barak [104]; Wise et al. [75]; Zhu et al. [10] }\end{array}$ \\
\hline Review of Educational Research & 1 & Joksimović et al. [13] \\
\hline $\begin{array}{l}\text { Australasian Journal of Educational } \\
\text { Technology }\end{array}$ & 1 & Lee et al. [15] \\
\hline Educational Research Review & 1 & Hew and Cheung [105] \\
\hline $\begin{array}{l}\text { Journal of Open, Flexible, and } \\
\text { Distance Learning }\end{array}$ & 1 & Jacoby [106] \\
\hline
\end{tabular}

Table 5. Conceptual frameworks (continued)

\begin{tabular}{|c|c|}
\hline References & Conceptual framework mobilised \\
\hline Alario-Hoyos et al. [85] & $\begin{array}{l}\text { Self-Regulated Learning Strategies in MOOCs (Cohen \& } \\
\text { Magen-Nagar, 2016; Hood et al., 2015; Zimmerman 2002) }\end{array}$ \\
\hline Andersen and Ponti [54] & $\begin{array}{l}\text {-Social interaction in the learning process (Dysthe, 2001; } \\
\text { Säljö, 2001). } \\
\text {-Zone of proximal development (Engeström, 1987) } \\
\text {-Mutual development (Andersen \& Mørch, 2009). }\end{array}$ \\
\hline Chen and Chen [42] & -Self-determination theory (Ryan \& Deci, 1985, 2002) \\
\hline Cheng [77] & $\begin{array}{l}\text {-The framework of Pekrun (2006) the item carried (i.e., } \\
\text { affective, cognitive, motivational, expressive, and periph- } \\
\text { eral physiological), the emotional outcome (i.e., positive } \\
\text { versus negative), and the nature of emotion (i.e., achieve- } \\
\text { ment versus non-achievement oriented). }\end{array}$ \\
\hline Cohen and Magen-Nagar [27] & -Self-regulated learning (Pintrich, 2000) \\
\hline Costley and Lange [87] & $\begin{array}{l}\text { Total Diversity and Learning Theories (Mayer and Ander- } \\
\text { son, 1991; Moreno \& Mayer, 1999; Mayer, 2014; Paivio, } \\
\text { 1991) }\end{array}$ \\
\hline de Lima et al. [88] & Social networks theory (Freeman, 1977) \\
\hline Evans and Myrick [56] & -The diffusion of innovations approach (Rogers, 2010) \\
\hline Gameel [29] & $\begin{array}{l}\text {-The theory of independent learning and teaching (Moore, } \\
\text { 1973) }\end{array}$ \\
\hline Greene et al. [25] & -Implicit theory of intelligence (Dweck's, 2012) \\
\hline Henderikx et al. [58] & -Reasoned action approach (Fishbein \& Ajzen, 2010) \\
\hline Higashi et al. [63] & $\begin{array}{l}\text {-Achievement goal theory (Senko et al.2011, p. 26) } \\
\text {-Expectancy value theory (Ajzen \& Fishbein1977; } \\
\text { Fishbein \& Ajzen 1975; Lovett \& Anderson 1996; Wig- } \\
\text { field \& Eccles, 2000). }\end{array}$ \\
\hline Hone and El Said [44] & $\begin{array}{l}\text {-Framework which explores the factors which affect } \\
\text { MOOC (Marks et al., 2005) completion/learner retention: } \\
\text { *Course instructor effects } \\
\text { *Co-learner effects } \\
\text { *Design features of the course and implementation effects }\end{array}$ \\
\hline Huisman et al. [36] & $\begin{array}{l}\text {-Peer assessment of essay assignments in MOOCs (Admi- } \\
\text { raal, Huisman, \& Van de Ven (2014) }\end{array}$ \\
\hline Jézégou [82] & $\begin{array}{l}\text {-A social-cognitive approach of self-directed learning } \\
\text { (Square, 2003, 2010; Christopher, 2011; Jezegou, 2011, } \\
\text { 2013) }\end{array}$ \\
\hline Kizilcec et al. ; Littlejohn et al. [100] & $\begin{array}{l}\text {-Fundamentals of instructional design (Dick, Carey \& } \\
\text { Carey, 2009) } \\
\text {-Connectivist learning theory (Siemens, 2005) }\end{array}$ \\
\hline
\end{tabular}




\begin{tabular}{|c|c|}
\hline & $\begin{array}{l}\text {-Self-directed learning (Barnard, Lan, To, Paton \& Lai, } \\
\text { 2009). } \\
\text {-Learner engagement (Milligan, Littlejohn \& Margaryan, } \\
\text { 2013; Andersen \& Ponti, 2014) }\end{array}$ \\
\hline Koutropoulos et al. [71] & $\begin{array}{l}\text {-Framework of learner engagement (Henri, 1992) } \\
\text {-Social presence (De Wever et al. 2010) } \\
\text {-Social constructivism (Gunawardena, Carabajal, \& Low- } \\
\text { er, 2001) } \\
\text {-Critical thinking (Webb, Newman, \& Cochrane, 1994) }\end{array}$ \\
\hline Kwak [92] & $\begin{array}{l}\text {-Writing as a skill } \\
\text {-Creative writing } \\
\text {-Writing as a process } \\
\text {-Writing as a social practice } \\
\text {-Writing in a socio-cultural context }\end{array}$ \\
\hline Milligan and Littlejohn [101] & -Self-regulated learning (Zimmerman, 2000) \\
\hline Phan et al. [47] & $\begin{array}{l}\text {-A framework for interaction and cognitive engagement in } \\
\text { a connectivist learning environments (Wang, Chen \& } \\
\text { Anderson, 2014) }\end{array}$ \\
\hline Poce [79] & $\begin{array}{l}\text {-Assessment of critical thinking (Newman, Web, \& } \\
\text { Cochrane, 1997) }\end{array}$ \\
\hline Shapiro et al. [48] & $\begin{array}{l}\text {-Student motivations (Hartnett, St. George, \& Dron, 2011), } \\
\text { barriers/challenges (Song \& Hill, 2007) }\end{array}$ \\
\hline Wang et al. [40] & $\begin{array}{l}\text {-Theory of self-determination (Ryan \& Deci, 2002). } \\
\text {-Theory of planned behaviour (Ajzen \& Madden, 1986). }\end{array}$ \\
\hline Watson, Loizzo et al. [65] & $\begin{array}{l}\text {-Dissonance theory (Kamradt \& Kamradt, 1999; Simon- } \\
\text { son, 1979; Simonson, \& Maushak 1996) }\end{array}$ \\
\hline Watted and Barak [104] & $\begin{array}{l}\text {-Motivational factors that influence participants' engage- } \\
\text { ment in MOOCs (Barak et al., 2016; Halasek et al., 2014; } \\
\text { Yang, 2014) }\end{array}$ \\
\hline Weller and Anderson [81] & -Digital resilience (Walker et al, 2004) \\
\hline Yang et al. [96] & $\begin{array}{l}\text {-Theoretical model for studying learners' continuance } \\
\text { intentions toward } \\
\text { participation in MOOCs }\end{array}$ \\
\hline Zhang [51] & -Regulatory focus theory (Higgins, 1997, 1998) \\
\hline Zhang, Skryabin and Song [61] & $\begin{array}{l}\text {-Social network analysis (SNA) (Xu, Zhang, Li, \& Yang, } \\
\text { 2015) }\end{array}$ \\
\hline Zhou [52] & $\begin{array}{l}\text {-Theory of self-determination (Ryan \& Deci, 2002). } \\
\text {-Theory of planned behaviour (Ajzen \& Madden, 1986). }\end{array}$ \\
\hline
\end{tabular}

